\title{
PERANCANGAN INSTRUMEN PENGUKUR KETINGGIAN MENGGUNAKAN SENSOR ADXL345 YANG TERKONEKSI DENGAN SMARTPHONE BERBASIS ANDROID
}

\author{
Asep Najmurrokhman ${ }^{1,}$, Kusnandar $^{1}$, Bambang HSR Wibowo ${ }^{1}$, Ariel Muhamad Annas ${ }^{1}$ \\ ${ }^{1}$ Jurusan Teknik Elektro, Universitas Jenderal Achmad Yani \\ JI. Terusan Jenderal Sudirman PO Box 148 Cimahi 40533, Indonesia \\ aemail : asepnajmu@yahoo.com
}

\begin{abstract}
Abstrak. Pengukuran ketinggian secara manual menggunakan alat ukur dengan rentang ukur terbatas dapat menghambat kinerja aktivitas pembangunan gedung. Untuk menangani masalah tersebut, sebuah perangkat diperlukan untuk dapat mengukur ketinggian gedung dengan lebih cepat, memiliki batas ukur yang lebih besar, dan mudah digunakan pada pengukuran bangunan bagian dalam yang berada pada satu bidang datar. Makalah ini mendeskripsikan hasil penelitian berupa instrumen pengukur ketinggian menggunakan sensor akselerometer ADXL345 yang terkoneksi dengan smartphone berbasis Android. Komponen lain yang membangun sistem ini adalah sensor ultrasonik HC-SR04, modul Bluetooth HC-05, dan mikrokontroler Arduino Uno. Sistem yang telah dirancang mampu terkoneksi dengan smartphone berbasis Android melalui koneksi dari modul bluetooth $\mathrm{HC}-05$, mengambil data jarak melalui pembacaan sensor ultrasonik dan data sudut elevasi melalui sensor ADXL345, mengirimkan atau menerima data dari smartphone Android ke Arduino dan sebaliknya, melakukan penghitungan ketinggian, dan menampilkannya pada aplikasi Android. Hasil pengujian menunjukkan aplikasi yang dibuat dalam perangkat smartphone berbasis Android dapat menampilkan hasil pengukuran ketinggian yang dilakukan. Perangkat yang dibuat dapat menghitung ketinggian bangunan secara cepat dengan persentase kesalahan sebesar $2,5 \%$. Jarak maksimum dari perangkat terhadap gedung diperoleh $1,75 \mathrm{~m}$.
\end{abstract}

Kata kunci: android, arduino, metode trigonometri, pengukuran ketinggian, sensor jarak, sensor sudut.

\section{Pendahuluan}

Mengukur panjang atau tinggi benda dengan menggunakan alat ukur panjang konvensional dibatasi oleh skala ukurnya. Alat ukur konvensional biasanya tidak dapat digunakan untuk mengukur benda atau bangunan yang tinggi. Untuk kepentingan tersebut diperlukan sebuah alat ukur yang lebih canggih untuk mengukur ketinggian bangunan. Pada umumnya, alat pengukur ketinggian gedung atau tanah menggunakan theodolite yang harganya relatif mahal [1]. Theodolite merupakan alat yang paling canggih di antara peralatan yang digunakan dalam survei. Pada dasarnya alat ini berupa sebuah teleskop yang ditempatkan pada suatu dasar berbentuk membulat (piringan) yang dapat diputar-putar mengelilingi sumbu vertikal, sehingga memungkinkan sudut horisontal untuk dibaca. Teleskop tersebut juga dipasang pada piringan kedua dan dapat diputar mengelilingi sumbu horisontal, sehingga memungkinkan sudut vertikal untuk dibaca. Dengan kemajuan dalam teknologi mikroelektronika khususnya fabrikasi perangkat sensor elektronik, instrumen ukur dapat dibuat lebih murah, lebih kecil, dan lebih praktis. Beberapa penelitian terkait dengan instrumen alat ukur ketinggian dengan menggunakan sensor elektronik diantaranya sensor level air untuk mengukur ketinggian muka air pada bendungan [2], sensor infra merah untuk mengukur tinggi lompatan dalam uji lompatan atlet [3], dan sensor ultrasonik dalam alat ukur tinggi badan [4].

Sementara itu, penetrasi pengguna smartphone diperkirakan menyentuh angka dua milyar pada tahun 2015 [5]. Smartphone telah berevolusi menjadi sebuah mesin komputasi yang unggul dengan kemampuan yang luar biasa. Dewasa ini, smartphone diperkaya fungsionalitasnya dengan penambahan sensor-sensor dalam perangkatnya. Hal tersebut menyebabkan pengguna memperoleh beragam manfaat dalam penggunaannya. Selain itu, operasi Android yang digunakan 
untuk menjalankan smartphone mendorong pengguna untuk dapat memaksimalkan fungsi smartphone dengan melakukan kustomisasi dalam setiap program yang diinstalasi ke dalamnya.

Makalah ini menguraikan tentang pemanfaatan smartphone berbasis Android untuk merealisasikan sebuah instrumen pengukur ketinggian dengan sensor accelerometer tipe ADXL345 sebagai komponen utama yang dapat mendeteksi sudut elevasi. Selanjutnya, data yang diperoleh dari sensor kemudian diolah oleh mikrokontroler dan ditampilkan dalam smartphone. Beberapa penelitian telah menggunakan sensor ADXL345 untuk aplikasi tertentu, diantaranya deteksi benda bergerak untuk kepentingan analisis kinematiknya [6], deteksi percepatan untuk aplikasi self-balancing robot [7], dan rancang bangun alat ukur getaran [8]. Sementara itu, Kim \& Kwon (2016) menggunakan ADXL345 sebagai sensor akselerometer untuk aplikasi monitoring kondisi kesehatan pasien yang dipantau kesehatannya dari aktivitas hariannya [9]. Selain sensor tersebut, instrumen yang dirancang juga menggunakan sensor jarak yaitu sensor tipe HC-SR04 yang digunakan untuk mengetahui jarak horizontal bangunan yang diukur dengan instrumen. Sensor HC-SR04 adalah sensor yang bekerja dengan prinsip penjalaran dan pemantulan gelombang ultrasonik. Selanjutnya, data sensor disimpan dan diolah oleh mikrokontroler Arduino, kemudian dikirim ke smartphone melalui koneksi bluetooth. Dengan menggunakan data yang diperoleh dari dua sensor tersebut, ketinggian benda atau bangunan dihitung dengan prinsip trigonometri sederhana. Selanjutnya, hasil pengukuran ditampilkan secara visual dalam perangkat tersebut.

\section{Perancangan dan Realisasi Sistem}

Diagram blok instrumen yang dirancang diperlihatkan pada Gambar 1. Berdasarkan Gambar 1, dua buah sensor yaitu ADXL345 dan HC-SR04 digunakan dalam instrumen ini. Sebuah mikrokontroler tipe Arduino Uno R3 difungsikan sebagai pengolah utama data yang diproses dalam instrumen tersebut. Sementara itu, motor servo dimanfaatkan untuk menggerakkan laser pointer sebagai penanda ketinggian yang akan diukur. Koneksi data dari mikrokontroler ke smartphone atau sebaliknya menggunakan modul bluetooth HC-05.

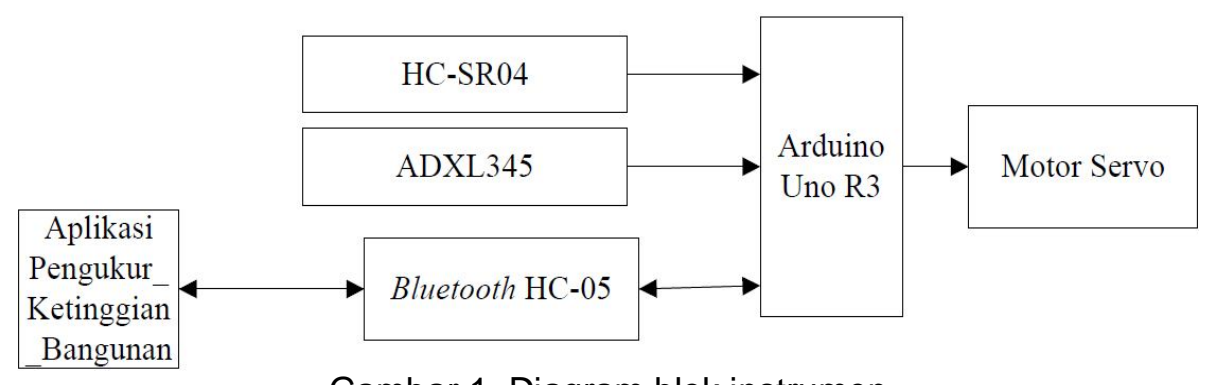

Gambar 1. Diagram blok instrumen

Sensor ADXL345 adalah sensor accelerometer yang dipakai untuk memperoleh sudut elevasi antara gedung yang diukur dengan garis horizontal, sedangkan sensor $\mathrm{HC}-\mathrm{SRO} 4$ adalah sensor ultrasonik yang dimanfaatkan untuk mengetahui jarak horizontal antara benda atau gedung yang diukur dengan instrumen. ADXL345 adalah modul sensor gerak/akselerasi 3 sumbu beresolusi 13 bit yang dapat mendeteksi tarikan pada jangkauan hingga $16 \mathrm{~g}$ ( $\mathrm{g}=$ percepatan gravitasi). Aplikasinya mencangkup mendeteksi kemiringan dengan memantau perubahan gaya tarik statis dan percepatan dinamis yang timbul akibat gerakan atau tumbukan. Dengan resolusi tinggi yang dihasilkannya, sensor ini mampu mendeteksi inklinasi pada tingkat yang sangat halus kurang dari $1^{\circ}$. Modul ini dapat mendeteksi status aktivitas gerakan (active/inactive) dengan membandingkan percepatan/akselerasi pada sumbu manapun dengan ambang batas sensitivitas yang dapat diatur melalui kode program. Selain itu, modul ini menyediakan pendeteksi ketukan (tap sensing) yang dapat mendeteksi ketukan tunggal maupun ganda pada berbagai arah. Modul ini juga dapat mendeteksi gerak jatuh bebas (free-fall sensing). Fungsi-fungsi tersebut dapat dipetakan secara terpisah pada dua pin keluaran yang terdapat dalam perangkat tersebut. Modul ini memiliki sistem pengelola memori internal statis sepanjang 32 bit bertipe antrian FIFO (first-in first-out) yang dapat digunakan untuk menyimpan variabel/data temporer hasil pengukuran sehingga mengurangi 
beban mikrokontroler dan secara umum menurunkan konsumsi energi sistem. Modul ini memiliki sirkuit pengelolaan daya yang canggih dimana modul ditempatkan pada mode konsumsi daya yang sangat kecil hingga terdeteksi gerakan yang melewati ambang batas (treshold) tertentu yang mengaktifkan kembali mode normal. Setelah proses pembacaan selesai secara otomatis modul dikembalikan ke mode siaga untuk menghemat energi. Bentuk fisik ADXL345 diperlihatkan pada Gambar 2.

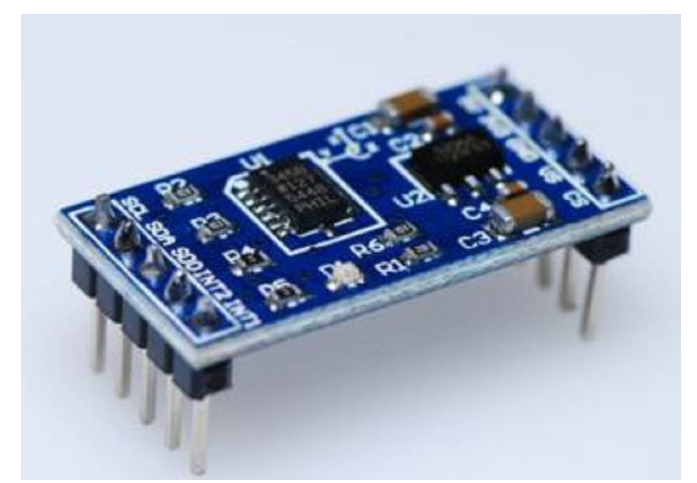

Gambar 2. Sensor accelerometer ADXL345

Sementara itu, sensor HC-SR04 merupakan sensor ultrasonik siap pakai yang berfungsi sebagai pengirim, penerima, dan pengontrol gelombang ultrasonik. Perangkat ini bisa digunakan untuk mengukur jarak benda dari $2 \mathrm{~cm}$ sampai dengan $4 \mathrm{~m}$ dengan tingkat akurasi $3 \mathrm{~mm}$. Sensor ini memiliki 4 pin, yaitu Vcc, GND, Trig, dan Echo. Pin Echo untuk listrik positif dan GND untuk ground-nya. Pin Trig difungsikan untuk pemicu sinyal yang dikirim dari sensor, sedangkan pin Echo digunakan untuk menangkap sinyal pantul dari benda yang akan diukur. Bentuk fisik sensor HC-SR04 diperlihatkan pada Gambar 3.

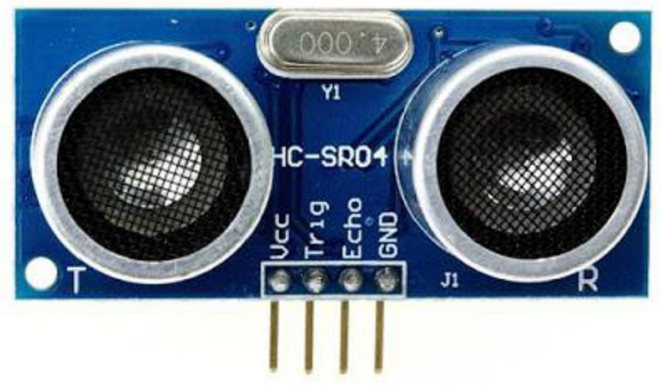

Gambar 3. Sensor Ultrasonik HC-SR04

Pada sensor ultrasonik, gelombang ultrasonik dibangkitkan melalui sebuah material yang disebut dengan piezoelektrik dengan frekuensi tertentu. Piezeolektrik ini akan menghasilkan gelombang ultrasonik (umumnya berfrekuensi $40 \mathrm{kHz}$ ) ketika sebuah osilator diterapkan pada sensor tersebut. Secara umum, alat ini akan menembakkan gelombang ultrasonik menuju suatu area atau suatu target. Setelah gelombang menyentuh permukaan target, maka target akan memantulkan kembali gelombang tersebut. Gelombang pantulan dari target akan ditangkap oleh sensor, kemudian sensor menghitung selisih antara waktu pengiriman gelombang dan waktu gelombang pantul diterima. Mekanisme pengukuran jarak dengan sensor ultrasonik diberikan pada Gambar 4.

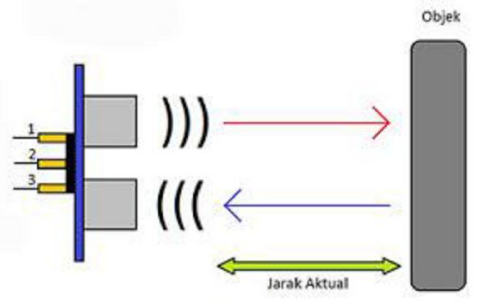

Gambar 4. Cara Kerja Sensor Ultrasonik 
Sebagai pengolah utama dalam sistem instrumentasi ini, mikrokontroler tipe Arduino Uno R3 digunakan untuk mengolah data dan menghubungkan komponen dalam sistem tersebut. Mikrokontroler tipe Arduino Uno R3 adalah papan pengembangan mikrokontroler berbasis chip ATmega328P. Arduino Uno memiliki 14 digital pin input/output dengan enam pin diantaranya dapat digunakan sebagai output PWM, enam pin input analog, menggunakan osilator kristal $16 \mathrm{MHz}$, koneksi USB, header ICSP, dan tombol reset. Bentuk fisik mikrokontroler tersebut diperlihatkan pada Gambar 5.

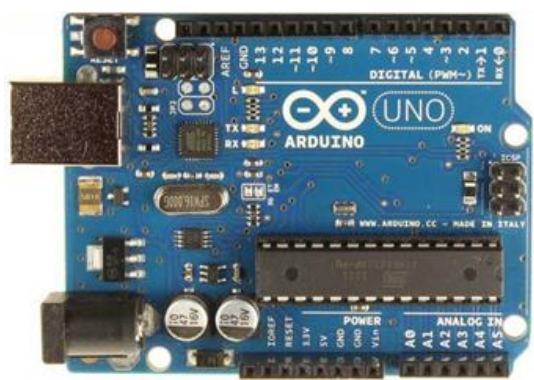

Gambar 5. Mikrokontroler Arduino Uno

Seluruh komponen yang digunakan dalam instrumen yang dirancang ditempatkan dalam suatu kotak plastik berwarna hitam dengan dimensi tinggi $5 \mathrm{~cm}$, panjang $12 \mathrm{~cm}$, dan lebar $8 \mathrm{~cm}$. Bentuk kompak perangkat yang dirancang diberikan pada Gambar 6. Pada bagian depan kotak tersebut terdapat lubang dua buah untuk menempatkan bagian transmitter dan receiver sensor ultrasonik. Selain itu, sebuah laser pointer dipasang untuk memberikan penanda bagian atas benda atau bangunan yang akan diukur tingginya. Pointer tersebut dapat bergerak secara bebas melalui mekanime gerak yang dihasilkan oleh motor servo. Gerak motor servo diatur melalui instruksi yang dikirim dari smartphone.

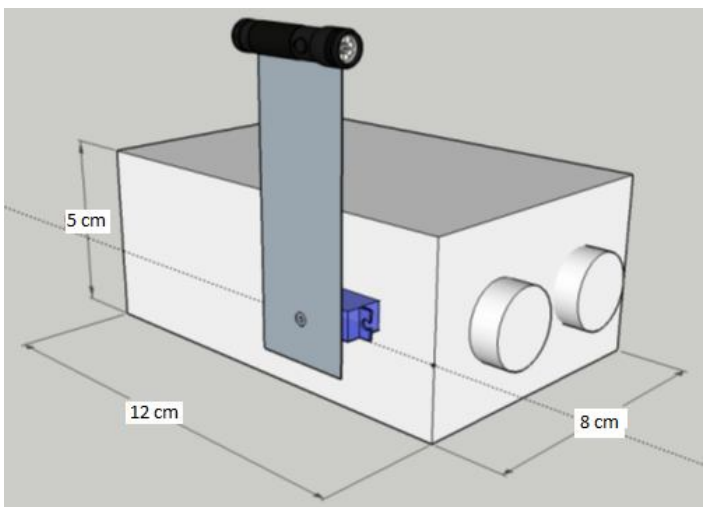

Gambar 6. Bentuk kompak instrumen yang dirancang

Sementara itu, program aplikasi yang dibuat dan ditampilkan dalam smartphone diberikan pada Gambar 7. Dalam tampilan tersebut, bagian 1 digunakan untuk mengakses daftar alamat dan nama bluetooth yang tersedia, sedangkan bagian 2 difungsikan untuk mengaktifkan aplikasi dengan alamat dan nama bluetooth yang sudah dipilih. Bagian 3 dipakai untuk menggerakkan motor servo dalam perangkat alat ukur yang dibuat. Motor servo digerakkan naik turun dengan menekan bagian 4 dan 5 , sedangkan laser pointer dinyalakan dengan menekan bagian 6 . Bagian 7 adalah hasil pembacaan sensor ADXL345, sedangkan bagian 9 menandai hasil pembacaan sensor jarak HC-SR04. Bagian 8 diisi dengan nilai ketinggian instrumen dari alasnya. Setelah semua data yang diperlukan terisi, tombol bagian 10 digunakan untuk mengeksekusi hasil perhitungan dan ditampilkan di bagian 11. 


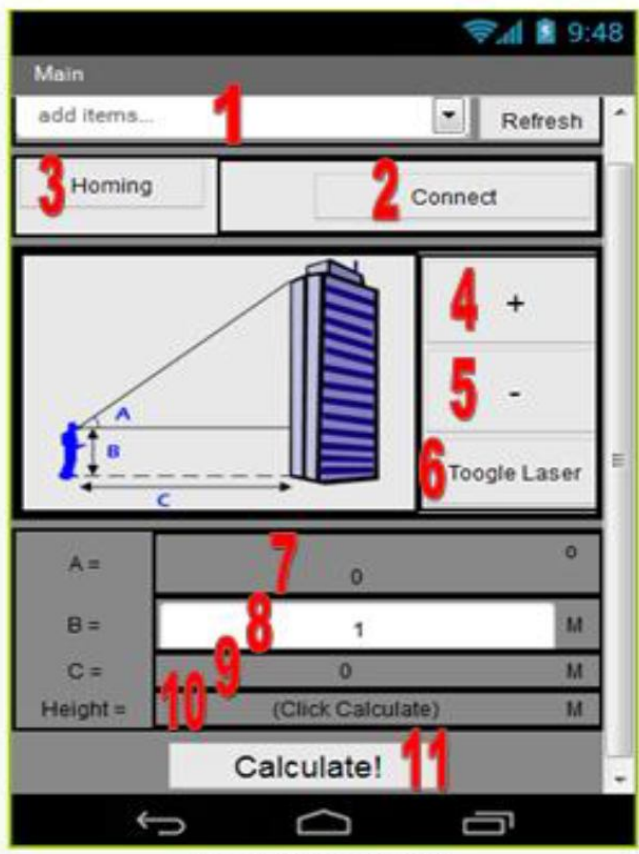

Gambar 7. Menu perhitungan ketinggian dalam smartphone

Untuk memperoleh sistem instrumentasi pengukur ketinggian yang diharapkan, interkoneksi antara komponen sensor dan modul bluetooth dengan mikrokontroler diberikan pada Gambar 8.
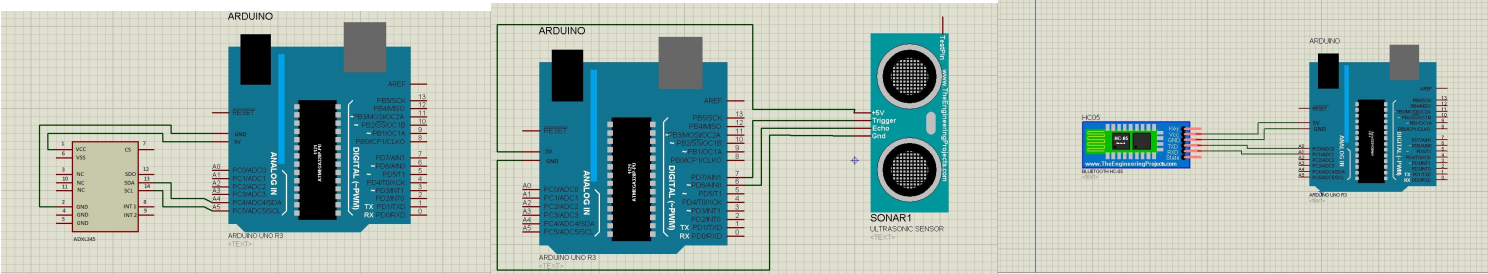

Gambar 8. Koneksi antar sensor dan modul bluetooth dengan mikrokontroler

Sementara itu, bentuk fisik dari instrumen diberikan pada Gambar 9.

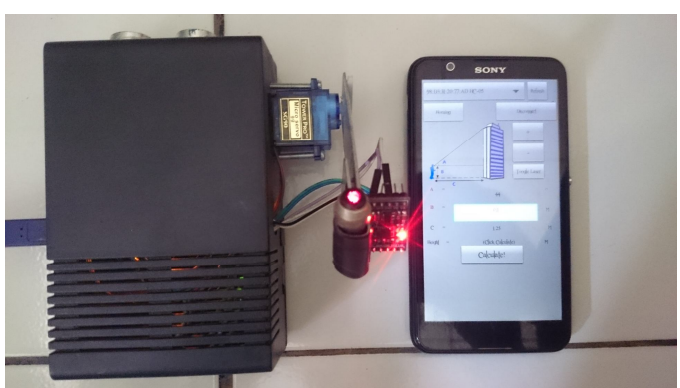

(a) tampak atas

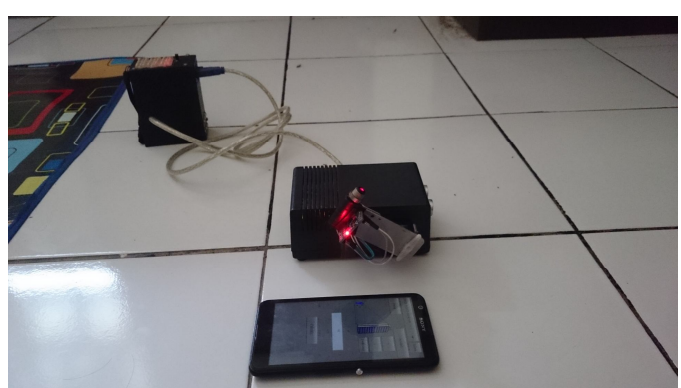

(b) tampak samping

Gambar 9. Realisasi instrumen pengukur ketinggian

\section{Hasil pengujian dan diskusi}

Pengujian pembacaan sensor dilakukan dengan cara membandingkan antara nilai yang muncul di serial monitor Arduino IDE dengan yang telah dikirimkan ke interface Android melalui bluetooth secara acak. Sensor ADXL345 akan mengikuti pergerakan motor servo karena diletakan sebidang. Apabila motor servo digerakkan melalui tombol yang ada pada interface Android ke 
atas, ke bawah, dan ke posisi semula untuk mendapatkan nilai data pembacaan sensor dan membandingkannya dengan nilai yang muncul pada serial monitor Arduino IDE, maka pembacaan sensor ADXL345 dapat dilakukan. Hasil pengujian memperlihatkan pembacaan sensor ADXL345 sama dengan yang ditampilkan pada interface Android sehingga dapat dijadikan sebagai data acuan pengukuran. Sementara itu, pengujian sensor ultrasonik dilakukan dengan cara membandingkan hasil pembacaan sensor untuk jarak horizontal antara instrumen dengan dinding bangunan yang akan diukur dengan ukuran sebenarnya. Hasil pengujian sensor ultrasonik diberikan pada Tabel 1.

Tabel 1. Pengujian Sensor Ultrasonik HC-SR04

\begin{tabular}{|c|c|}
\hline Data sensor $(\mathrm{m})$ & Jarak sebenarnya $(\mathrm{m})$ \\
\hline 0 & 0.01 \\
\hline 0 & 0.02 \\
\hline 0.15 & 0.15 \\
\hline 0.3 & 0.30 \\
\hline 0.5 & 0.50 \\
\hline 1.2 & 1.20 \\
\hline 1.34 & 1.35 \\
\hline 1.61 & 1.60 \\
\hline 2.32 & 2.30 \\
\hline 2.67 & 2.65 \\
\hline
\end{tabular}

Berdasarkan Tabel 1, hasil pengujian sensor ultrasonik dapat dijadikan sebagai data acuan pengukuran jarak horizontal antara instrumen dengan bangunan yang akan diukur.

Setelah semua komponen diintegrasikan, pengujian instrumen alat ukur yang dirancang dilakukan dengan cara membandingkan hasil-hasil pengukuran sensor dan perhitungan ketinggian oleh program aplikasi yang diinstalasi dalam smartphone dengan ketinggian sebenarnya yang diukur secara manual. Dalam pengujian tersebut, instrumen alat ukur diletakkan $1 \mathrm{~m}$ di atas tanah. Hasil pengujiannya diberikan dalam Tabel 2. Berdasarkan hasil pengujian tersebut, instrumen pengukur ketinggian yang dirancang memperlihatkan ketepatan pengukuran dengan baik. Persentase kesalahan pengukuran yang dihasilkan sekitar 2,5\%.

Tabel 2. Hasil Pengujian Keseluruhan Sistem

\begin{tabular}{|c|c|c|c|}
\hline $\begin{array}{c}\text { Pembacaan sensor } \\
\text { ADXL345 }\left({ }^{\circ}\right)\end{array}$ & $\begin{array}{c}\text { Pembacaan sensor HC- } \\
\text { SR04 }(\mathrm{m})\end{array}$ & $\begin{array}{c}\text { Ketinggian yang } \\
\text { ditampilkan dalam } \\
\text { smartphone }(\mathrm{m})\end{array}$ & $\begin{array}{c}\text { Ketinggian hasil } \\
\text { perhitungan manual } \\
(\mathrm{m})\end{array}$ \\
\hline $30^{\circ}$ & 0.25 & 1.14 & 1,14 \\
\hline $30^{\circ}$ & 0.5 & 1.28 & 1,29 \\
\hline $30^{\circ}$ & 0.75 & 1.43 & 1,43 \\
\hline $30^{\circ}$ & 1 & 1.58 & 1,58 \\
\hline $30^{\circ}$ & 1.25 & 1.72 & 1,72 \\
\hline $30^{\circ}$ & 1.5 & 1.87 & 1,87 \\
\hline $30^{\circ}$ & 1.75 & 2.5 & 2,01 \\
\hline $45^{\circ}$ & 0.25 & 1.25 & 1,25 \\
\hline $45^{\circ}$ & 0.5 & 1.50 & 1,50 \\
\hline $45^{\circ}$ & 0.75 & 1.75 & 2,75 \\
\hline $45^{\circ}$ & 1 & 2.00 & 2,00 \\
\hline $45^{\circ}$ & 1.25 & 2.25 & 2,25 \\
\hline $45^{\circ}$ & 1.5 & 2.50 & 2,75 \\
\hline $45^{0}$ & 1.75 & 2.75 & 1,43 \\
\hline $60^{\circ}$ & 0.25 & 1.43 & 1,87 \\
\hline $60^{\circ}$ & 0.5 & 1.87 & 2,30 \\
\hline $60^{\circ}$ & 0.75 & 2.29 & 2,73 \\
\hline $60^{\circ}$ & 1 & 2.73 & 3,17 \\
\hline $60^{\circ}$ & 1.25 & 3.17 & 3,60 \\
\hline $60^{\circ}$ & 1.5 & 3.59 & 4,03 \\
\hline $60^{\circ}$ & 1.75 & 4.03 & \\
\hline & & & \\
\hline & & & \\
\hline
\end{tabular}




\section{Kesimpulan}

Makalah ini telah membahas tentang perancangan dan realisasi sebuah prototipe instrumen pengukur ketinggian menggunakan sensor accelerometer ADXL345 sebagai sensor pendeteksi kemiringan dan sensor ultrasonik HC-SR04 sebagai sensor pengukur jarak horizontal antara instrumen dengan benda atau bangunan yang akan diukur ketinggiannya. Data dari sensor kemudian diproses oleh mikrokontroler untuk kemudian dikirim melalui modul bluetooth ke perangkat smartphone berbasis Android. Data dari sensor dan hasil pengukuran ditampilkan dalam perangkat smartphone tersebut. Hasil pengujian menunjukkan bahwa prototipe instrumen yang dirancang memberikan ketepatan pengukuran dengan tingkat kesalahan sekitar 2,5\%.

\section{Daftar Pustaka}

[1] S. Gill and A. Aryan, To Experimental Study for Comparison Theodolite and Total Station, Inter. J. of Eng. Research \& Science 2 (3), 153-160, 2016.

[2] Suleman dan Sahebatie, Rancangan Prototipe Alat Pengukur Tinggi Muka Air Pada Bendungan, Jurnal Evolusi II (2), 83-89, September 2014.

[3] F.S. Pribadi, S. Haryono, Rancang Bangun Alat Ukur Ketinggian Lompatan Dengan Sensor Infra Merah, Jurnal Teknik Elektro 3 (1), 20-25, 2011.

[4] R.S Akbar, Pengukur Tinggi Badan Berbasis Arduino, Jurnal Ilmiah Mikrotek 1 (4), 198-2014, 2015.

[5] C.A. Kardous and P. B. Shaw, Evaluation of smartphone sound measurement applications, J. Acoust. Soc. Am. 135 (4), 186-192, April 2014.

[6] M.C.A Carascoa, J.P.P Pizarroa, G.A. Tapanga, Development of A Microcontroller Based Wireless Accelerometer for Kinematic Analysis, J. Mechatron. Electr. Power Veh. Technol 06, $1-8,2015$.

[7] H. Ferdinando, H. Khoswanto, D. Purwanto, Performance Evaluation of MMA7260QT and ADXL345 on Self Balancing Robot, TELKOMNIKA 11 (1), 1-10, March 2013.

[8] A.Z. Rohman dan Djuniadi, Rancang Bangun Alat Ukur Getaran Menggunakan Sensor Micro Electro Mechanical System (MEMS) Akselerometer, Edu Elektrika Journal 4 (1), 8-16, 2015

[9] S.Y. Kim and G.I. Kwon, Interrupt-Based Step-Counting to Extend Battery Life in an Activity Monitor, Journal of Sensors, 2016, http://dx.doi.org/10.1155/2016/5824523. 